
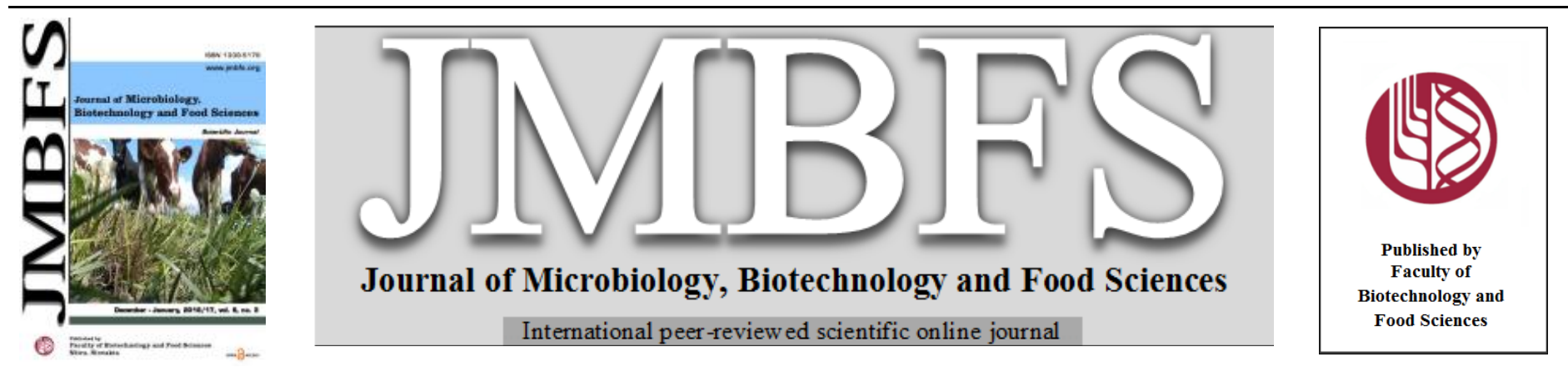

\title{
INDUCTION OF CALLUS FROM LEAF AND STEM TISSUES OBTAINED FROM CAPSICUM ANNUUM EXPLANT GROWN ON WASTE ENGINE OIL-POLLUTED SOILS
}

\author{
Beckley Ikhajiagbe ${ }^{1 *}$, Ralph Chukwuemeka Eke ${ }^{2}$, and Betsy Osasumwen Guobadia ${ }^{1}$
}

\author{
Address(es): \\ ${ }^{1}$ Environmental Plant Biotechnology and Sustainability Research Group, Department of Plant Biology \& Biotechnology, Univ. of Benin, Benin City, Nigeria. Tel: \\ +2348037094470 . \\ ${ }^{2}$ Plant Physiology Division, Nigerian Institute for Oil Palm Research, Benin City, Nigeria.
}

*Corresponding author: beckley.ikhajiagbe@uniben.edu

doi: 10.15414/jmbfs.2016/17.6.3.966-971

ARTICLE INFO

Received 5. 9. 2016

Revised 21. 10. 2016

Accepted 25. 10. 2016

Published 1. 12. 2016

Regular article

OPEN ${ }_{\text {ACCESS }}$

\begin{abstract}
The present study investigated callusing frequency of explants from leaf and stem tissues obtained from Capsicum annuum explant exposed to waste engine oil contamination. The explants obtained from 21-31 days old seedlings were cultured on Murashige and Skoog (MS) medium supplemented with various concentrations of BAP $(0,1,2,3,4,5$ and $6 \mathrm{mg} / \mathrm{l})$ and NAA, IAA, 2, 4-D and IBA $(0,5,10$, 15 and $20 \mathrm{mg} / \mathrm{l})$. Results showed that efficient callusing in leaves and stems explants (21 days old) was achieved after explants were cultured on MS semi-solid media containing 1-5 mg/l BAP and 0.5-1.5 mg/l IBA for 4 weeks; while callus formation was hindered in older tissues. An effective protocol for callogenesis of 21 day-old explants (stems) of $C$. annuum obtained from oil-polluted soil in a semi-solid state MS medium using BAP and IBA was thus developed. The study also documented the ability of IBA to induce callus.
\end{abstract}

Keywords: Callus, Callogenesis, morphogenesis, explant, tissue culture, oil-polluted soil

\section{INTRODUCTION}

In order to survive poor economic conditions, there is usually the option of diversification of income by poor locals. One of such is the proliferation of alternative employment like artisans including auto mechanics. In many povertyimpoverished countries, particularly in the third world, there seem to have been an increase in the siting of mechanic workshops as well workshops of other artisans which use and dispose of engine oils and other waste petroleum products (Ikhajiagbe, 2010; Ikhajiagbe and Anoliefo, 2012a). These workshops range from repairers of automobiles, industrial machines and engines, as well as generating sets. These mechanics replace engine oil from motor vehicle and generator engines, and other machines. The engine oil wastes are in most cases disposed inappropriately into open vacant plots and fields as well as drainages. This action directly or indirectly leads to soil pollution with oil and its constituents; thus leading to phytotoxicity. The adverse impact oil and watersoluble factions of oil have on plant growth and development, as well as oversell crop yield has been reported (Vwioko and Fashemi, 2005; Ikhajiagbe, 2010).

The impact of oil on plants starts from germination. Ikhajiagbe et al. (2014) reported effects of oil on germination parameters of Vigna unguiculata. Anoliefo and Vwioko (1995) also reported reduced germination rate of Capsicum frutescens and Zea mays due to oil pollution. The inhibitory effects of oil on seed germination may be due to a number of reasons including physical limitations and biological impairment on the seeds (Amakiri and Onofeghara, 1984). When this occurs, crop sustainability can no longer be guaranteed, particularly during the time when the clamour for food security seems loudest. The idea of possible regeneration and proliferation of seedlings to guarantee the sustenance of species and species lines is thus imperative. This informs the basis of the study.

Recent works by Ikhajiagbe (2010) and Ikhajiagbe and Anoliefo (2012a, b) showed that soil polluted by waste engine oil resulted in chlorosis and the death of the crop plants sown within five (5) months of pollution. This finding was for current oil-in-soil concentrations of above $5 \% \mathrm{w} / \mathrm{w}$. This begs the question whether it was possible for any crop plant that was sown in oil-polluted soil within 5 months of pollution to be regenerated from explants of such plants. If this were achieved, then it would be possible to save the oil-threatened plants. In the present study, pepper (Capsicum annuum L.) has been selected. Capsicum annиит L. plays a vital part in many cuisines. Apart from their use as spices, pepper contains capsaicin which has use in many pharmaceutical preparations. This plant species is usually propagated by seed; however the use of tissue culture has become an important tool in clonal propagation and breeding programs.

Although there are not yet documented evidences that oil pollution currently threatens the in vitro regeneration of peppers, the possibility is not far-fetched, especially in a world that now revolves round the petroleum sector. The need to address this possible threat is not the only rationale for the study; there is also the need to satisfy the ever-increasing demand for the crops. This therefore calls for more dependable breeding methods for mass proliferation of the crop in the face of the present challenges.

Most plants in oil-contaminated soils accumulate heavy metals and toxic poly aromatic hydrocarbons leading to chlorosis and eventually, necrosis (Ikhajiagbe, 2010). When this happens, harvesting explants for the purpose of regeneration or other in vitro studies can become very challenging. The present study intends to find out at what time in the pepper's developmental phase where successful explants exposed to waste engine oil polluted soil can be regenerated using tissue culture techniques. The objective is to induce callus from leaf and stem tissues obtained from $C$. annuum explant grown on polluted soils, employing standard In vitro techniques and using defined medium, supplemented with various combinations of plant growth hormones and to determine the growth rate of callus formation.

\section{MATERIAL AND METHODS}

This study was carried out in the Tissue Culture Laboratory, Physiology and Tissue Culture Division, Nigerian Institute for Oil Palm Research (NIFOR), located at 1735 land area, $29 \mathrm{~km}$ off the City centre, off Benin - Akure Road, Benin, Edo State, Nigeria.

\section{Collection and preparation of materials for the experiment}

Top soil $(0-10 \mathrm{~cm})$ was collected from a cleared field, beside Tissue Culture Laboratory (NIFOR) and sun-dried to constant weight. Thereafter, $12.5 \mathrm{~kg}$ of the sun-dried soil was collected using shovel and hand trowel, weighed (using measuring scale) and poured into ten (10) perforated nursery bags with three replicates labeled as control. Waste engine oil obtained as pooled from an automechanic workshop was added to the soil; this was thoroughly mixed to obtain a constant concentration of 5\%w/w WEO-in-soil. The bags of soil were left for one month to attenuate, after which physiochemical parameters of polluted and control soils were determined (Table 1). Thereafter, planting of 
viable pepper seeds (which were pre-soaked in water for ten hours) were carried out in the morning (7am) and left to grow for a month.

\section{Collection of Explants}

Stem and leaf explants were randomly collected at three different ages; 21,28 and 31 days old. These three (3) age groups were preferred because previous reports by Ikhajiagbe (2010) revealed that plants sown in $2.5-10.0 \% \mathrm{w} / \mathrm{w}$ oilpolluted soil began to show signs of physiological stress within 2 weeks (or 14 days) of exposure to polluted soils. These explants were cultured In vitro.

\section{Development of MS protocol for explants}

The callusing efficiencies of Capsicum annuum leaf and stem explants were examined by using Murashige and Skoog (MS) basal medium (Murashige and Skoog, 1962) with different concentrations of plant growth regulators (PGRs). However, modified MS protocols were developed for the purpose of the study for explant regeneration. In developing the MS protocols, stock solutions were first prepared using the facilities of Tissue Culture Laboratory of the Nigerian Institute for Oil Palm Research (NIFOR), Benin City, Nigeria. All the apparatus used were thoroughly washed, rinsed twice and dried using the oven at $65^{\circ} \mathrm{C}$ for 1 hour. After preparation, the solutions were stored in a refrigerator at $60^{\circ} \mathrm{C}$.

\section{Stock Solutions}

MS Macro x10 (500ml): Two hundred (200) $\mathrm{ml}$ of distilled water was poured in a 400ml Pyrex bottle and placed on a magnetic stirrer with the stirring bar and allowed to stir for about 5mins. A measured $9.5 \mathrm{~g}$ of potassium nitrate $\left(\mathrm{KNO}_{3}\right)$ $8.25 \mathrm{~g}$ of ammonium nitrate $\left(\mathrm{NH}_{4} \mathrm{NO}_{3}\right)$, and $0.85 \mathrm{~g}$ of potassium dihydrogen orthophosphate $\left(\mathrm{KH}_{2} \mathrm{PO}_{4}\right), 2.2 \mathrm{~g}$ of calcium chloride dehydrate $\left(\mathrm{Cl} .2 \mathrm{H}_{2} \mathrm{O}\right)$ and $1.85 \mathrm{~g}$ of Magnesium sulphate $\left(\mathrm{MgSO}_{4} .7 \mathrm{H}_{2} \mathrm{O}\right)$ were weighed and poured into the bottle. After pouring the first compound, it was allowed to stir for 5 - $7 \mathrm{mins}$ before the other compounds were added. The solution was poured into a $500 \mathrm{ml}$ measuring cylinder and rinsed with distilled water. It was then made to $500 \mathrm{~m}$ and stored for use in a 1-litre flask.

MS Micro A x10 (500ml): A measured $250 \mathrm{ml}$ of distilled water was poured into a $400 \mathrm{ml}$ Pyrex bottle, which was placed on a magnetic stirrer (with the stirring bar) and allowed to stir. Thereafter, $1.11 \mathrm{~g}$ of Maganous sulphate $\left(\mathrm{MnSO}_{4} \cdot 4 \mathrm{H}_{2} \mathrm{O}\right)$, $0.315 \mathrm{~g}$ of Boric acid $\left(\mathrm{H}_{3} \mathrm{BO}_{3}\right), 0.43 \mathrm{~g}$ of zinc sulphate $\left(\mathrm{ZnSO}_{4} .7 \mathrm{H}_{2} \mathrm{O}\right)$ and $0.415 \mathrm{~g}$ of potassium iodide were weighed and added into the stirring bottle. After $10 \mathrm{mins}$, it was turned into a $500 \mathrm{ml}$ measuring cylinder and then made up to the mark. The solution was stored for use.

MS Micro B (500ml): Distilled water $(300 \mathrm{ml})$ was measured into a $400 \mathrm{ml}$ Pyrex bottle which was placed on a magnetic stirrer (with the stirring rod). Measured qualities $(0.125 \mathrm{~g})$ of sodium molybdate $\left(\mathrm{Na}_{2} \mathrm{MOD}_{4} .2 \mathrm{H}_{2} \mathrm{O}\right), 0.0125 \mathrm{~g}$ of cupric acid $\left(\mathrm{CuSO}_{4} .5 \mathrm{H}_{2} \mathrm{O}\right)$ and $0.0125 \mathrm{~g}$ of cobalt chloride $\left(\mathrm{Cl}_{2} \cdot 6 \mathrm{H}_{2} \mathrm{O}\right)$ were poured into the bottle. After $10 \mathrm{mins}$, it was turned into a measuring cylinder and then made up to the $500 \mathrm{ml}$ mark

MS Iron x100 (500ml): Fifty (50) $\mathrm{ml}$ of distilled water was poured into a conical flask (containing stirring bar) and placed on a hot plate. Measured $1.865 \mathrm{~g}$ of ethylene diamine tetraacetic acid (EDTA) was weighed into a conical flask and allowed to heat at $260^{\circ} \mathrm{C}$ for 10 mins. Thereafter, $1.39 \mathrm{~g}$ of ferrous sulphate $\left(\mathrm{FeSO}_{4} .7 \mathrm{H}_{2} \mathrm{O}\right)$ was weighed into a beaker containing $30 \mathrm{ml}$ of water which was placed on a stirrer machine and allowed to dissolve. This was poured into the EDTA solution and allowed to heat for 10mins, and thereafter made up to the $500 \mathrm{ml}$ mark.

MS Vitamins x100 (500ml): $200 \mathrm{ml}$ of distilled water was poured into a $400 \mathrm{ml}$ Pyrex bottle which was placed on a magnetic stirrer and allowed to stir. Then $0.25 \mathrm{~g}$ of thiamine-HCL, $0.125 \mathrm{~g}$ of pyridoxine-HCL, $0.25 \mathrm{~g}$ of Nicotinic acid, $0.1 \mathrm{~g}$ of Glycine acid and $0.125 \mathrm{~g}$ of calcium parthotenate were weighed and poured into the Pyrex bottle. After 10mins the entire solution mixture was turned into a measuring cylinder and made up to the $500 \mathrm{ml}$ mark.

\section{Establishment of MS protocol (1000ml) for 21 and 28 day-old explants}

Macro x10 $100 \mathrm{ml}$

Micro (A and B) x100 ------------------------------------------- 10ml

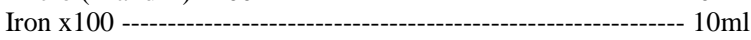

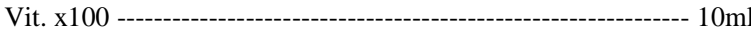

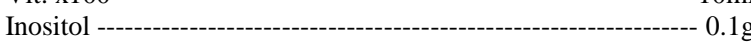

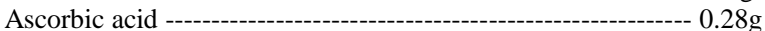

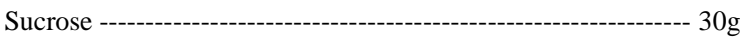

The media were divided into 28 bottles of $36 \mathrm{ml}$ each

\section{MS Medium for pepper (28days old) callogenesis}

Full strength MS medium supplemented with $30 \mathrm{~g}$ sucrose, macro x10, micro x10 $A$ and $\mathrm{B}$, iron $\times 100$,vitamins $\times 100$, plant growth hormones (PGH). $36 \mathrm{ml}$ of the solution was dispensed into 28 bottles, each containing $0.35 \mathrm{~g}$ of agar $\mathrm{pH}$ of 5.8 An aliquot of $12 \mathrm{ml}$ was dispensed into 84 labeled (control and polluted) screwcap McCartney bottles, three replicates of each concentrations of PGH, autoclaved and allowed to cool at ambient temperature $\left(28^{\circ} \mathrm{C}\right)$. The explants (stems and leaves) were removed from the plants, rinsed with tap water; surface sterilized using $5 \%$ hypochlorite solution (containing a drop of Tween ${ }_{20}$ ) for 5 mins. Sterile water was used to remove traces of sodium hypochlorite solution five times to get rid of the sterilizing solution which is toxic to the stems and leaves on delayed exposure. The explants were cut into thin sections (using sterilized forceps and surgical blades on sterilized Petri dishes) and transferred aseptically into the test tubes containing the culture medium using sterilized forceps (i.e. inoculation) and covering them up immediately with aluminium foil passed over flame. They were then incubated in the dark growth room at $27^{\circ} \mathrm{C}$ for 6 weeks.

\section{MS Medium for pepper (21days old) callogenesis}

The medium was in semi-solid state. The amount of agar used was reduced to $0.28 \mathrm{~g}$ for $36 \mathrm{ml}$ of the solution. The explants (stems) were removed from the plants, rinsed with tap water; surface sterilized using $0.4 \%$ mercuric chloride $\left(\mathrm{HgCl}_{2}\right)$ solution containing a drop of Tween 20 for 5 mins. Traces of the $\mathrm{HgCl}_{2}$ were removed by rinsing with sterile distilled water five times to get rid of the sterilizing solution which is toxic to the stems and leaves on prolonged exposure. The explants were cut into thin sections (using sterilized forceps and surgical blades on sterilized Petri dishes) and transferred aseptically into the test tubes containing the culture medium using sterilized forceps (i.e. inoculation) and covering them up immediately with aluminium foil passed over flame. They were then incubated in the dark growth room at $27^{\circ} \mathrm{C}$ for 8 weeks.

\section{Establishment of MS protocol (1350ml) for 31day-old explants}

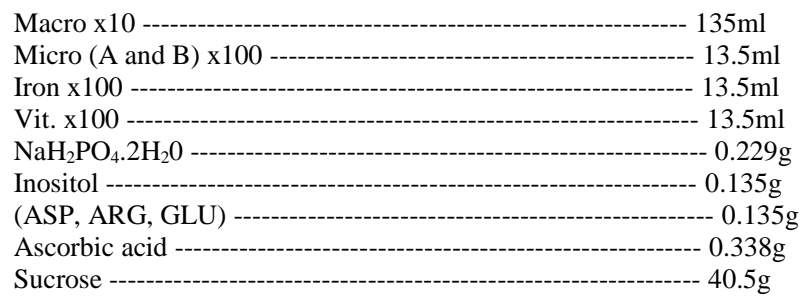

Then, the media were divided into 45 bottles of $30 \mathrm{ml}$ each

\section{MS Medium for pepper (31 days old) callogenesis}

Standard MS medium is supplemented with $40.5 \mathrm{~g}$ sucrose, macro $\mathrm{x} 10$, micro $\mathrm{x} 10$ A and B, iron x100,vitamins x100, plant growth hormones (PGH). Measured quantity $(30 \mathrm{ml})$ of the solution was dispensed into 45 bottles, each containing $0.28 \mathrm{~g}$ of agar $\mathrm{pH}$ of 5.8 . An aliquot of $10 \mathrm{ml}$ was dispensed into 135 labeled (control and polluted) test tubes $(50 \mathrm{ml})$, three replicates of each concentrations of $\mathrm{PGH}$, autoclaved and allowed to cool at ambient temperature $\left(28^{\circ} \mathrm{C}\right)$. The explants (stems and leaves) were removed from the plants, rinsed with tap water; surface sterilized using $5 \%$ hypochlorite solution (containing a drop of Tween ${ }_{20}$ ) for 5 mins. Sterile water was used to remove traces of sodium hypochlorite solution five times to get rid of the sterilizing solution which is toxic to the stems and leaves on delayed exposure. The explants were cut into thin sections (using sterilized forceps and surgical blades on sterilized Petri dishes) and transferred aseptically into the test tubes containing the culture medium using sterilized forceps (i.e. inoculation) and covering them up immediately with aluminium foil passed over flame. They were then incubated in the dark growth room at $27^{\circ} \mathrm{C}$ for 8 weeks. The media were prepared in the main laboratory and the initiation was carried out in the Laminar flow cabinet.

Plant growth hormones (PGH) modification and supplementation for 31days old pepper

Three types of auxins and one cytokinin were used. The auxins used were Indole acetic acid (IAA), Naphthalene acetic acid (NAA) and 2,4 dichlorophenoxyl acetic acid (2,4-D), each at concentrations of $0,1.5,3,4.5$ and $6 \mathrm{mg} / \mathrm{L}$. The cytokinin used was Benzyl amino purine (BAP) at concentrations of $0,0.1$ and 1 $\mathrm{mg} / \mathrm{L}$ (Table 2).

\section{Testing the effects of IAA and BAP}

IAA at concentrations of $1.5,3,4.5$ and $6 \mathrm{mg} / \mathrm{L}$ as well as BAP at concentrations of 0.1 and $1 \mathrm{mg} / \mathrm{L}$ was added. Control experiment without IAA and BAP was 
also included. The possible combinations for various concentrations of the two PGH (IAA and BAP) led to an experiment with 15 treatments.

\section{Testing the effects of NAA and BAP}

NAA at concentrations of $1.5,3,4.5$ and $6 \mathrm{mg} / \mathrm{L}$ as well as 0.1 and $1 \mathrm{mg} / \mathrm{L}$ concentrations of BAP were added. Control experiment without NAA and BAP was also included. The possible combinations for various concentrations of the two PGH (NAA and BAP) led to an experiment of 15 treatments.

\section{Testing the effects of 2, 4-D and BAP}

2, 4-D at concentrations of $1.5,3,4.5$ and $6 \mathrm{mg} / \mathrm{L}$ and $\mathrm{BAP}$ at concentrations of 0.1 and $1 \mathrm{mg} / \mathrm{L}$ were added. Control experiment without 2, 4-D and BAP was also included. The possible combinations for various concentrations of the two PGH (2, 4-D and BAP) led to an experiment with 15 treatments.

Plant growth hormones (PGH) modification and supplementation for 28 and 21days old pepper

One type of auxin and one cytokinin were used. The auxin used was Indole butyric acid (IBA) at concentrations of $0,0.5,1$ and $1.5 \mathrm{ppm}$. The cytokinin used was Benzyl amino purine (BAP) at concentrations of $0,1,2,3,4,5$ and 6 ppm (Table 3)

\section{Testing the effects of IBA and BAP}

IBA at concentrations of $0.18,0.36$ and $0.54 \mathrm{mg} / \mathrm{L}$ as well as $0.36,0.72,1.08$ 1.44, 1.8 AND 2.16 MG/L concentrations of BAP were added. Contro experiment without IBA and BAP was also included. The possible combinations for various concentrations of the two PGH (IBA and BAP) led to an experiment of 28 treatments.

\section{Determination of source of contamination in inoculum}

In other to ascertain contamination rate for explants obtained from control and polluted soils, swaps from the contaminated media were taken and cultured on PDA and nutrient agar media, using the spread plate method (Cheesebrough, 2001).

\section{Experimental Design}

The experimental design chosen was the completely randomized design (CRD) As a result, treatments were randomized over the media. Each treatment consisted of 3 replicates. The treatments were the various levels of Indole acetic acid (IAA), Naphthalene acetic acid (NAA), 2,4 dichlorophenoxyl acetic acid (2,4-D), Indole butyric acid (IBA) and Benzyl amino purine (BAP) in the media In order to avoid bias and misidentification, treatment bottles were properly labeled according to a given treatment name and replicate number. Results were presented as mean \pm standard error.

\section{RESULTS}

The aim of this experiment was to study the growth of callus formation from pepper (Capsicum annuиm L.) leaf and stem explants, obtained from polluted soils (see Table 1), employing standard in vitro techniques and using defined medium, supplemented with various combinations of cytokinin and auxins. Results showed that naphthalene acetic acid (NAA) and Benzyl amino purine (BAP) supplemented on solid media resulted in the callogenesis of the control 31 day-old stem explants. Callus initiation was obtained at the concentrations of 1.5 and $4.5(\mathrm{mg} / \mathrm{l})$ after 8 weeks. This treatment showed a low percentage of callogenesis. Callogenesis did not occur in the Indole acetic acid (IAA) and Benzyl amino purine (BAP)-amended media, as well as in the 2, 4 dichlorophenoxyl acetic acid (2,4-D) and Benzyl amino purine (BAP) media However, $33.3 \%$ callogenesis was obtained in the control explants in the $0.1 \mathrm{mgl}$ ${ }^{1} \mathrm{BAP} / 1.5 \mathrm{mgl}^{-1}$ IAA combination (Table 4). No callus was obtained in the polluted treatments. Similarly, $66.7 \%$ callogenesis was obtained in $1.0 \mathrm{mgl}^{-1}$ BAP/4.5 mgl - $^{-1}$ NAA combination. Appropriate combinations of $0.1 \mathrm{mgl}^{-1}$ BAP/1.5 mgl ${ }^{-1}$ IAA as well as $1.0 \mathrm{mgl}^{-1} \mathrm{BAP} / 4.5 \mathrm{mgl}^{-1}$ IAA showed $33.3 \%$ and $66.7 \%$ callogenesis respectively in control explants (Table 5). No callus was obtained in the polluted experiments. Similar results were obtained with the $\mathrm{BAP} / 2,4$ - D combinations (Table 6$)$. The addition of IBA $(0$ and $1.0 \mathrm{mg} / \mathrm{l})$ to the culture medium containing different BAP levels greatly stimulated further callus proliferation beyond the levels obtained for IAA and 2, 4-D (see Table 7). However, there was no callus formation when the concentration of IBA was increased to $1.5 \mathrm{mg} / \mathrm{l}$ at any given BAP concentration.

Callus induction with IBA/BAP-supplemented semi-solid medium at various levels of concentration of both the control and polluted explants source (21days old) after 2 weeks of initiation was reported (Table 8). The age of the explants and medium state greatly stimulated further callus proliferation beyond the levels obtained for other treatments. Fresh weight of callus was obtained at increased concentrations $(3,4,5$ and 6$)$ of BAP in polluted plant source, and control source $(1,2,4$ and 5). Calli formations were effective when the plant's (pepper) age was 21days old, medium state (which was in semi-solid state) and the type of sterilant $\left(\mathrm{HgCl}_{2}\right)$ used. Callus was induced with IBA in combination with the cytokinin, BAP at various levels of concentration. The use of semi-solid medium containing different levels of concentrations stimulated further callus proliferation beyond the levels obtained from other treatment.

Results also showed that the contamination rate for leaf and stem explants $(31,28$ and 21days) obtained from control and polluted soils (Table 9). The rate shows seven days interval after inoculation of the explants. For the 31day-old leaf explants; the contaminated media after 8 weeks indicates fungal infection. This observation is similar to the 31day-old stem explants. The contaminated media for both 28 day-old leaf and stem explants indicates bacterial infection after 8 weeks. Results for the 21 day-old leaf and stem explants indicate bacterial and fungal infections respectively. Young plant tissues possess higher capability for response to in vitro culture, compared to older plant materials. This may explain the favourable responses recorded for the young stem explants. The standard medium for callogenesis of Capsicum annuum has been presented to be the semisolid state MS medium that is enhanced with BAP 1, 2, 3, 4 and 5 and IBA 0.5 and $1.5,0$ and $1,0,0.5,0.5$ and $1.5 \mathrm{mg} \mathrm{L}^{-1}$. Survival rate of the established calli ranged from $60-80 \%$, and were kept in a dark growth room. The study confirms attainment of maximum callogenesis as long as proper concentrations of plant growth hormones were applied.

Table 1 Physicochemical properties of soil at one month after pollution, prior to sowing of pepper

\begin{tabular}{lcc}
\hline Parameters & Unpolluted soil & Oil-polluted soil \\
\hline $\mathrm{pH}$ & 5.59 & 5.47 \\
Electric conductivity $(\mu \mathrm{s} / \mathrm{cm})$ & 289 & 339 \\
Total organic carbon $(\%)$ & 0.59 & 2.32 \\
Total nitrogen $(\%)$ & 0.15 & 0.29 \\
$\mathrm{Na}(\mathrm{meq} / 100 \mathrm{~g}$ soil) & 11.10 & 11.10 \\
$\mathrm{~K}(\mathrm{meq} / 100 \mathrm{~g}$ soil) & 1.16 & 1.16 \\
$\mathrm{Ca}(\mathrm{meq} / 100 \mathrm{~g}$ soil) & 22.30 & 22.30 \\
$\mathrm{Mg}(\mathrm{meq} / 100 \mathrm{~g}$ soil) & 15.40 & 15.40 \\
$\mathrm{Fe}(\mathrm{mg} / \mathrm{kg})$ & 720.34 & 997.64 \\
$\mathrm{Mn}(\mathrm{mg} / \mathrm{kg})$ & 13.64 & 11.70 \\
$\mathrm{Zn}(\mathrm{mg} / \mathrm{kg})$ & 10.36 & 21.80 \\
$\mathrm{Cu}(\mathrm{mg} / \mathrm{kg})$ & $<0.01$ & 2.60 \\
$\mathrm{Cr}(\mathrm{mg} / \mathrm{kg})$ & $<0.01$ & 1.60 \\
$\mathrm{Cd}(\mathrm{mg} / \mathrm{kg})$ & $<0.01$ & 0.12 \\
$\mathrm{~Pb}(\mathrm{mg} / \mathrm{kg})$ & $<0.01$ & 1.26 \\
$\mathrm{Ni}(\mathrm{mg} / \mathrm{kg})$ & $<0.01$ & 0.70 \\
$\mathrm{~V}(\mathrm{mg} / \mathrm{kg})$ & $<0.01$ & 0.64 \\
$\mathrm{Total} \mathrm{hydrocarbon} \mathrm{content}(\mathrm{mg} / \mathrm{kg})$ & 100.78 & 1268.00 \\
\hline
\end{tabular}

Table 2 A schematic arrangements of treatments used for explants obtained at 31 days. $\mathrm{pH}-5.8$, Agar - $0.28 \mathrm{~g}$

\begin{tabular}{|c|c|c|c|c|c|}
\hline & 0ppm & 5ppm & 10ppm & 15ppm & 20ppm \\
\hline \multicolumn{6}{|c|}{$\mathbf{N A A}_{100 p p m} / \mathbf{B A P}_{100 \mathrm{ppm}}$} \\
\hline 0ppm & $0 \mathrm{ml} / 0 \mathrm{ml}$ & $1.5 \mathrm{ml} / 0 \mathrm{ml}$ & $3 \mathrm{ml} / 0 \mathrm{ml}$ & $4.5 \mathrm{ml} / 0 \mathrm{ml}$ & $6 \mathrm{ml} / 0 \mathrm{ml}$ \\
\hline 0.1ppm & $\begin{array}{c}0 \mathrm{ml} / \\
0.03 \mathrm{ml}\end{array}$ & $1.5 \mathrm{ml} /$ & $3 \mathrm{ml} /$ & $4.5 \mathrm{ml} / 0.03 \mathrm{ml}$ & $6 \mathrm{ml} / 0.03 \mathrm{ml}$ \\
\hline 1ppm & $0 \mathrm{ml} / 0.3 \mathrm{ml}$ & $1.5 \mathrm{ml} / 0.3 \mathrm{ml}$ & $3 \mathrm{ml} / 0.3 \mathrm{ml}$ & $4.5 \mathrm{ml} / 0.3 \mathrm{ml}$ & $6 \mathrm{ml} / 0.3 \mathrm{ml}$ \\
\hline IA $\mathbf{A}_{100 p p m}$ & $\mathbf{B A P}_{100 \mathrm{ppm}}$ & & & & \\
\hline 0ppm & $0 \mathrm{ml} / 0 \mathrm{ml}$ & $1.5 \mathrm{ml} / 0 \mathrm{ml}$ & $3 \mathrm{ml} / 0 \mathrm{ml}$ & $4.5 \mathrm{ml} / 0 \mathrm{ml}$ & $6 \mathrm{ml} / 0 \mathrm{ml}$ \\
\hline 0.1ppm & $\begin{array}{c}0 \mathrm{ml} / \\
0.03 \mathrm{ml}\end{array}$ & $\begin{array}{l}1.5 \mathrm{ml} / \\
0.03 \mathrm{ml}\end{array}$ & $\begin{array}{c}3 \mathrm{ml} / \\
0.03 \mathrm{ml}\end{array}$ & $4.5 \mathrm{ml} / 0.03 \mathrm{ml}$ & $6 \mathrm{ml} / 0.03 \mathrm{ml}$ \\
\hline $\begin{array}{l}1 \mathrm{ppm} \\
2,4-\mathrm{D}_{100 \mathrm{pp}}\end{array}$ & $\begin{array}{l}0 \mathrm{ml} / 0.3 \mathrm{ml} \\
{ }_{\mathbf{n}} / \mathbf{B} \mathbf{A} \mathbf{P}_{\mathbf{1 0 0 p p m}}\end{array}$ & $1.5 \mathrm{ml} / 0.3 \mathrm{ml}$ & $3 \mathrm{ml} / 0.3 \mathrm{ml}$ & $0.3 \mathrm{ml}$ & $6 \mathrm{ml} / 0.3 \mathrm{ml}$ \\
\hline 0ppm & $0 \mathrm{ml} / 0 \mathrm{ml}$ & $1.5 \mathrm{ml} / 0 \mathrm{ml}$ & $3 \mathrm{ml} / 0 \mathrm{ml}$ & $4.5 \mathrm{ml} / 0 \mathrm{ml}$ & $6 \mathrm{ml} / 0 \mathrm{ml}$ \\
\hline 0.1ppm & $\begin{array}{c}0 \mathrm{ml} / \\
0.03 \mathrm{ml}\end{array}$ & $\begin{array}{l}1.5 \mathrm{ml} / \\
0.03 \mathrm{ml}\end{array}$ & $\begin{array}{c}3 \mathrm{ml} / \\
0.03 \mathrm{ml}\end{array}$ & $4.5 \mathrm{ml} / 0.03 \mathrm{ml}$ & $6 \mathrm{ml} / 0.03 \mathrm{ml}$ \\
\hline 1ppm & $0 \mathrm{ml} / 0.3 \mathrm{ml}$ & $1.5 \mathrm{ml} / 0.3 \mathrm{ml}$ & $3 \mathrm{ml} / 0.3 \mathrm{ml}$ & $4.5 \mathrm{ml} / 0.3 \mathrm{ml}$ & $6 \mathrm{ml} / 0.3 \mathrm{ml}$ \\
\hline
\end{tabular}

Table 3 A schematic arrangements of treatments applied to explants obtained from 21 and 28 days old plants. pH - 5.8; Agar - 0.35g (for 28day-old explants) and $0.28 \mathrm{~g}$ (for 21day-old explants).

\begin{tabular}{lllll}
\hline $\begin{array}{l}\mathbf{I B A}_{100 p p m} / \\
\text { BAP }_{\text {100ppm }}\end{array}$ & $\mathbf{0 p p m}$ & $\mathbf{0 . 5 p p m}$ & $\mathbf{1 p p m}$ & $\mathbf{1 . 5 p p m}$ \\
\hline $\mathbf{0 p p m}$ & $0 \mathrm{ml} / 0 \mathrm{ml}$ & $0.18 \mathrm{ml} / 0 \mathrm{ml}$ & $0.36 \mathrm{ml} / 0 \mathrm{ml}$ & $0.54 \mathrm{ml} / 0 \mathrm{ml}$ \\
$\mathbf{1 p p m}$ & $0 \mathrm{ml} / 0.36 \mathrm{ml}$ & $0.18 \mathrm{ml} / 0.36 \mathrm{ml}$ & $0.36 \mathrm{ml} / 0.36 \mathrm{ml}$ & $0.54 \mathrm{ml} / 0.36 \mathrm{ml}$ \\
$\mathbf{2 p p m}$ & $0 \mathrm{ml} / 0.72 \mathrm{ml}$ & $0.18 \mathrm{ml} / 0.72 \mathrm{ml}$ & $0.36 \mathrm{ml} / 0.72 \mathrm{ml}$ & $0.54 \mathrm{ml} / 0.72 \mathrm{ml}$ \\
$\mathbf{3 p p m}$ & $0 \mathrm{ml} / 1.08 \mathrm{ml}$ & $0.18 \mathrm{ml} / 1.08 \mathrm{ml}$ & $0.36 \mathrm{ml} / 1.08 \mathrm{ml}$ & $0.54 \mathrm{ml} / 1.08 \mathrm{ml}$ \\
$\mathbf{4 p p m}$ & $0 \mathrm{ml} / 1.44 \mathrm{ml}$ & $0.18 \mathrm{ml} / 1.44 \mathrm{ml}$ & $0.36 \mathrm{ml} / 1.44 \mathrm{ml}$ & $0.54 \mathrm{ml} / 1.44 \mathrm{ml}$ \\
$\mathbf{5 p p m}$ & $0 \mathrm{ml} / 1.8 \mathrm{ml}$ & $0.18 \mathrm{ml} / 1.8 \mathrm{ml}$ & $0.36 \mathrm{ml} / 1.8 \mathrm{ml}$ & $0.54 \mathrm{ml} / 1.8 \mathrm{ml}$ \\
$\mathbf{6 p p m}$ & $0 \mathrm{ml} / 2.16 \mathrm{ml}$ & $0.18 \mathrm{ml} / 2.16 \mathrm{ml}$ & $0.36 \mathrm{ml} / 2.16 \mathrm{ml}$ & $0.54 \mathrm{ml} / 2.16 \mathrm{ml}$ \\
\hline
\end{tabular}


Table 4 Effects of BAP and NAA in solid medium, callogenesis (\%) and weight (colour) of callus of C. annuum L.

\begin{tabular}{|c|c|c|c|c|c|}
\hline \multirow{2}{*}{ BAP $\mathrm{mgL}^{-1}$} & \multirow{2}{*}{ NAA mg ${ }^{-1}$} & \multicolumn{2}{|c|}{ Callogenesis (\%) } & \multicolumn{2}{|c|}{ Wt. $g$ (colour) of callus } \\
\hline & & Control & Polluted & Control & Polluted \\
\hline \multirow[t]{5}{*}{0} & 0 & $100 \pm 0$ & $100 \pm 0$ & $0.429 \pm 0.012$ (B) & $0.424 \pm 0.0 .098(\mathrm{C})$ \\
\hline & 1.5 & 0 & 0 & - & - \\
\hline & 3.0 & 0 & 0 & - & - \\
\hline & 4.5 & 0 & 0 & - & - \\
\hline & 6.0 & 0 & 0 & - & - \\
\hline \multirow[t]{5}{*}{0.1} & 0 & 0 & 0 & - & \\
\hline & 1.5 & $33.3 \pm 0.0$ & 0 & $0.350 \pm 0.0 .035(\mathrm{LB})$ & - \\
\hline & 3.0 & 0 & 0 & - & - \\
\hline & 4.5 & 0 & 0 & - & - \\
\hline & 6.0 & 0 & 0 & - & - \\
\hline \multirow[t]{5}{*}{1.0} & 0 & 0 & 0 & - & - \\
\hline & 1.5 & 0 & 0 & - & - \\
\hline & 3.0 & 0 & 0 & - & - \\
\hline & 4.5 & $66.7 \pm 0.0$ & 0 & $0.082 \pm 0.016(\mathrm{DB})$ & \\
\hline & 6.0 & 0 & 0 & - & - \\
\hline
\end{tabular}

Table 5 Combination of different concentrations of BAP and IAA in solid medium, callogenesis (\%) and weight (colour) of callus of C. апnиит L.

\begin{tabular}{|c|c|c|c|c|c|}
\hline \multirow{2}{*}{$\begin{array}{l}\mathrm{BAP} \\
\mathrm{mgL}^{-1}\end{array}$} & \multirow{2}{*}{$\begin{array}{l}\text { IAA } \\
\text { mg }\end{array}$} & \multicolumn{2}{|c|}{ Callogenesis (\%) } & \multicolumn{2}{|c|}{ Wt. g (colour) of callus } \\
\hline & & Control & Polluted & Control & $\begin{array}{l}\text { Polluted } \\
\end{array}$ \\
\hline \multirow[t]{5}{*}{0} & 0 & $100 \pm 0$ & $100 \pm 0$ & $\begin{array}{c}0.510 \pm 0.035 \\
\text { (B) }\end{array}$ & $0.452 \pm 0.083(\mathrm{C})$ \\
\hline & 1.5 & 0 & 0 & - & - \\
\hline & 3.0 & 0 & 0 & - & - \\
\hline & 4.5 & 0 & 0 & - & - \\
\hline & 6.0 & 0 & 0 & - & - \\
\hline \multirow{5}{*}{0.1} & 0 & 0 & 0 & - & \\
\hline & 1.5 & $33.3 \pm 0$ & 0 & $\begin{array}{c}0.054 \pm 0.009 \\
\text { (B) }\end{array}$ & - \\
\hline & 3.0 & 0 & 0 & - & - \\
\hline & 4.5 & 0 & 0 & - & - \\
\hline & 6.0 & 0 & 0 & - & - \\
\hline \multirow[t]{5}{*}{1.0} & 0 & 0 & 0 & - & - \\
\hline & 1.5 & 0 & 0 & - & - \\
\hline & 3.0 & 0 & 0 & - & - \\
\hline & 4.5 & $66.7 \pm 0$ & 0 & $\begin{array}{c}0.499 \pm 0.031 \\
\text { (DB) }\end{array}$ & \\
\hline & 6.0 & 0 & 0 & - & - \\
\hline
\end{tabular}

Legend: B- Brown; C- Cream; DB- Dark brown; LB- Light brown. Results have been presented as mean \pm standard error

Table 6 Effects of different concentrations of BAP and 2, 4-D in solid medium, callogenesis (\%) and weight (colour) of callus of $C$. аппиит $\mathrm{L}$.

\begin{tabular}{|c|c|c|c|c|c|}
\hline \multirow{2}{*}{$\begin{array}{l}\text { BAP } \\
m g L^{-1}\end{array}$} & \multirow{2}{*}{$\begin{array}{l}2,4-\mathrm{D} \\
\mathrm{mg}^{-1}\end{array}$} & \multicolumn{2}{|c|}{ Callogenesis (\%) } & \multicolumn{2}{|c|}{ Wt. $\mathrm{g}$ (colour) of callus } \\
\hline & & Control & Polluted & Control & Polluted \\
\hline \multirow[t]{5}{*}{0} & 0 & $100 \pm 0$ & $100 \pm 0.0$ & $\begin{array}{c}0.481 \pm 0.078 \\
\text { (B) }\end{array}$ & $\begin{array}{c}0.462 \pm 0.0 .046 \\
\text { (C) }\end{array}$ \\
\hline & 1.5 & 0 & 0 & - & - \\
\hline & 3.0 & 0 & 0 & - & - \\
\hline & 4.5 & 0 & 0 & - & - \\
\hline & 6.0 & 0 & 0 & - & - \\
\hline \multirow[t]{5}{*}{0.1} & 0 & 0 & 0 & - & \\
\hline & 1.5 & $33.3 \pm 0.0$ & 0 & $\begin{array}{c}0.114 \pm 0.027 \\
\text { (B) }\end{array}$ & - \\
\hline & 3.0 & 0 & 0 & - & - \\
\hline & 4.5 & 0 & 0 & - & - \\
\hline & 6.0 & 0 & 0 & - & - \\
\hline \multirow[t]{5}{*}{1.0} & 0 & 0 & 0 & - & - \\
\hline & 1.5 & 0 & 0 & - & - \\
\hline & 3.0 & 0 & 0 & - & - \\
\hline & 4.5 & $63.2 \pm 1.8$ & 0 & $\begin{array}{c}0.231 \pm 0.019 \\
\text { (C) }\end{array}$ & \\
\hline & 6.0 & 0 & 0 & - & - \\
\hline
\end{tabular}

Legend: B- Brown; C- Cream; DB- Dark brown; LB- Light brown. Results have been presented as mean \pm standard error
Table 7 Shows the effects of appropriate combinations of BAP and IBA in solid medium, callogenesis (\%) and weight (colour) of callus of C. аппиит $\mathrm{L}$.

\begin{tabular}{|c|c|c|c|c|c|}
\hline \multirow{2}{*}{$\begin{array}{l}\text { BAP } \\
\mathrm{mgL}^{-1}\end{array}$} & \multirow{2}{*}{$\begin{array}{l}\text { IBA } \\
\mathrm{mg}^{-1}\end{array}$} & \multicolumn{2}{|c|}{ Callogenesis (\%) } & \multicolumn{2}{|c|}{ Wt. g (colour) of callus } \\
\hline & & Control & Polluted & Control & Polluted \\
\hline \multirow[t]{4}{*}{0} & 0 & $100 \pm 0.0$ & $100 \pm 0$ & $\begin{array}{c}0.444 \pm 0.102 \\
\text { (B) }\end{array}$ & $\begin{array}{c}0.520 \pm 0.114 \\
\text { (C) }\end{array}$ \\
\hline & 0.5 & 0 & 0 & - & - \\
\hline & 1.0 & 0 & 0 & - & - \\
\hline & 1.5 & 0 & 0 & - & - \\
\hline \multirow[t]{4}{*}{1.0} & 0 & 0 & 0 & - & \\
\hline & 0.5 & 0 & 0 & - & - \\
\hline & 1.0 & $66.7 \pm 0.0$ & 0 & $\begin{array}{c}0.343 \pm 0.083 \\
\text { (C) }\end{array}$ & - \\
\hline & 1.5 & 0 & 0 & - & - \\
\hline \multirow[t]{4}{*}{2.0} & 0 & 0 & 0 & - & - \\
\hline & 0.5 & 0 & 0 & - & - \\
\hline & 1.0 & 0 & 0 & - & - \\
\hline & 1.5 & 0 & 0 & - & - \\
\hline \multirow[t]{4}{*}{3.0} & 0 & 0 & 0 & - & - \\
\hline & 0.5 & 0 & 0 & - & - \\
\hline & 1.0 & 0 & 0 & - & - \\
\hline & 1.5 & 0 & 0 & - & - \\
\hline \multirow[t]{4}{*}{4.0} & 0 & 0 & 0 & - & - \\
\hline & 0.5 & 0 & 0 & - & - \\
\hline & 1.0 & 0 & 0 & - & - \\
\hline & 1.5 & 0 & 0 & - & - \\
\hline
\end{tabular}

Legend: B- Brown; C- Cream; DB- Dark brown; LB- Light brown. Results have been presented as mean \pm standard error

Table 8 Effects of different concentrations of Benzyl amino purine (BAP) and Indole butyric acid (IBA) in a semi-solid state, callogenesis (\%) and weight (colour) of callus of $C$. annuum $L$.

\begin{tabular}{|c|c|c|c|c|c|}
\hline \multirow{2}{*}{$\begin{array}{l}\mathrm{BAP} \\
\mathrm{mgL}^{-1}\end{array}$} & \multirow{2}{*}{$\begin{array}{l}\mathrm{IBA} \\
\mathrm{mg}^{-1}\end{array}$} & \multicolumn{2}{|c|}{ Callogenesis (\%) } & \multicolumn{2}{|c|}{ Wt. $g$ (colour) of callus } \\
\hline & & Control & Polluted & Control & Polluted \\
\hline \multirow[t]{4}{*}{0} & 0 & $100 \pm 0.0$ & $100 \pm 0.0$ & $\begin{array}{c}0.544 \pm 0.102 \\
\text { (B) }\end{array}$ & $\begin{array}{c}0.613 \pm 0.11 \\
4(\mathrm{C})\end{array}$ \\
\hline & 0.5 & 0 & 0 & - & - \\
\hline & 1.0 & 0 & 0 & - & - \\
\hline & 1.5 & 0 & 0 & - & - \\
\hline \multirow[t]{4}{*}{1.0} & 0 & 0 & 0 & - & \\
\hline & 0.5 & $30.9 \pm 1.3$ & 0 & $\begin{array}{c}0.213 \pm 0.092 \\
\text { (B) }\end{array}$ & - \\
\hline & 1.0 & $33.3 \pm 0.0$ & $62.9 \pm 4.2$ & $\begin{array}{c}0.280 \pm 0.045 \\
\text { (C) }\end{array}$ & $\begin{array}{c}0.333 \pm 0.10 \\
0 \text { (B) }\end{array}$ \\
\hline & 1.5 & 0 & 0 & - & - \\
\hline \multirow[t]{4}{*}{2.0} & 0 & 0 & $100 \pm 0.0$ & - & $\begin{array}{c}0.563 \pm 0.13 \\
2(\mathrm{C})\end{array}$ \\
\hline & 0.5 & $33.3 \pm 0.0$ & 0 & $\begin{array}{c}0.034 \pm 0.008 \\
\text { (B) }\end{array}$ & - \\
\hline & 1.0 & $97.7 \pm 2.1$ & 0 & $\begin{array}{c}0.251 \pm 0.074 \\
\text { (B) }\end{array}$ & - \\
\hline & 1.5 & $33.3 \pm 0.0$ & 0 & $\begin{array}{c}0.232 \pm 0.062 \\
\text { (B) }\end{array}$ & - \\
\hline \multirow[t]{4}{*}{3.0} & 0 & 0 & $66.7 \pm 0.0$ & - & $\begin{array}{c}0.182 \pm 0.07 \\
5 \text { (LB) }\end{array}$ \\
\hline & 0.5 & 0 & 0 & - & - \\
\hline & 1.0 & 0 & $33.3 \pm 0.0$ & - & $\begin{array}{c}0.222 \pm 0.07 \\
3 \text { (B) }\end{array}$ \\
\hline & 1.5 & 0 & 0 & - & - \\
\hline
\end{tabular}




\begin{tabular}{cccccc}
\hline & 0.5 & $33.3 \pm 0.0$ & 0 & $0.138 \pm 0.088$ \\
$(\mathrm{C})$ & - \\
& & & & $0.031 \pm 0.011$ & - \\
& 1.0 & $33.3 \pm 0.0$ & 0 & $(\mathrm{~B})$ & - \\
5.0 & 1.5 & 0 & 0 & - & - \\
& 0 & 0 & 0 & - & - \\
& 0.5 & $33.3 \pm 0.0$ & 0 & $0.227 \pm 0.052$ & - \\
& & & & $0.125 \pm 0.037$ & - \\
& 1.0 & $31.7 \pm 1.9$ & 0 & $(\mathrm{DB})$ & - \\
& & & & $0.097 \pm 0.024$ & $0.572 \pm 0.1$ \\
6.0 & 1.5 & $33.3 \pm 0.0$ & $66.7 \pm 0.0$ & $(\mathrm{C})$ & $02(\mathrm{C})$ \\
& 0 & 0 & 0 & - & - \\
& 0.5 & 0 & 0 & - & - \\
& 1.0 & 0 & 0 & - & - \\
& 1.5 & 0 & 0 & - & - \\
\hline
\end{tabular}

Legend: B- Brown; C- Cream; DB- Dark brown; LB- Light brown. Results have been presented as mean \pm standard error

\section{DISCUSSION}

The most significant characteristic in plant tissue culture is the explant; and until the appropriate choice of explant effective regeneration may not be achieved. Bhojwani and Dantu (2013) reported that the most commonly used explant for most micropropagation work is either apical bud or nodal segment. In the present study, regeneration potential of leaf and stem explants was investigated. Auxins like Indoleacetic acid (IAA) and napthaleneacetic acid (NAA) generally stimulate cell expansion, particularly cell elongation; thus promoting adventitious root development. The capacity for NAA to initiate rapid tissue response even in very small amounts has been reported (Mineo, 1990). This auxin is relatively stable in plant tissues, and their hormonal influences last for extensive periods.

The functionality of most phytohormones, whether synthetic or natural, is not to the extent of acting in isolation within the plant body; the hormones rather function in relation to each other (Mineo, 1990). This may account for improved weights of calluses, as reported in the study, than when the auxins were used in isolation. Sharma and Shahzad (2008) also earlier reported no callus formation or seed germination in MS medium alone, during the induced regeneration from cotyledonary node explant of Abelmoschus moschatus. The capacity for NAA and BAP-supplemented MS medium to initiate callogenesis was reported Although the popularity of use of both indolebutyric acid and naphthaleneacetic acid for propagation of plants from stem and leaf cuttings have been well documented (Hopkins \& Hüner, 2009; Taiz \& Zeiger, 2010); the supplementation of the culture media with the hormones did not initiate callogenesis in polluted explants, except in the unpolluted. The presentation of differential callus colour as reported in the study is most likely due to differences in type of explant used, the solid state of the medium, as well as possible presence of contamination of explant or medium. Jin et al. (2014) reported significant changes in callus colour with increase in age of Pogostemon cablin callus, from white to green. Initial contamination of explant is a significant factor that determines the success of callus formation. Such contamination may be of biological origin, for example microbial contamination, or chemical. In the study, plants from which explants were obtained were originally exposed to waste oil pollution, and as such the possibility for contamination from phyto-accumulated oil constituents like heavy metals and polyaromatics suffice as like possible factors for poor callus initiation. This was generally reported in the study. However, in the BAP/IBA-supplement semi-solid medium, significant callogenesis was reported. Generally, the use of semi-solid medium containing different levels of concentrations stimulated further callus proliferation beyond the levels obtained from other treatment. Hormone stability is ostensibly more significant than the total concentration of any single hormone. It is also an important factor in considering the overall effects of hormones on plant growth and morphological changes. This therefore means that the hormone variances in the experimental media states (solid or semi-solid state) ought to generate rather dissimilar effects on the growth and development of excised explants. This may be responsible for the differences in percentage callogenesis and callus weight gain in the BAP/IBA-supplemented media in solid and semi-solid states (Mineo, 1990). Aghaei et al. (2013) earlier reported significant callus induction of stem explants in Pistacia atlantica subsp. Kurdica inoculated in IBA-supplemented medium. Similar reported were provided by Jin et al. (2014) in the in vitro propagation of Pogostemon cablin, and Caraballo et al. (2010) in Agave fourcroydes. Agrawal and Chandra (1983); Phillips and Hustenberger (1985); Agrawal et al. (1989); Harini and Sita (1993); Christopher and Rajam (1994, 1996); Hyde and Phillips (1996); Hassan et al. (1999) reported that at elevated concentrations of BAP and low levels of auxins, Capsicum аппиит could be regenerated from explants including hypocotyls and cotyledons. The study also reported significant callogenesis of the 21 day-old stem explants. Contamination rate for this treatment also gave a low result. The effectiveness of use of IBA in culture media has been further buttressed in this study. According to Sharma and Shahzad (2008), however, the inclusion of either $(0.05 \mathrm{mg} / \mathrm{L})$ IBA or $(0.05 \mathrm{mg} / \mathrm{L})$ NAA in BA-containing media did not improve the regeneration efficiency of Abelmoschus moschatus. In many other species similar combinations were advantageous for shoot multiplication as reported in Macuna pruriens (Bretagne et al., 1994). The magnitude of broad differentiation in tissue culture is subject to the hormonal balance of the support medium as well as the physiological state of the tissue, which usually swings in the direction of the young tissues than older ones (Mineo, 1990). Explants from numerous intact plant parts can be used to form callus. However, the most successful explants are often young tissues of one or a few cell types. More so, given the fact that some nutrients like nitrogen, phosphorus and potassium can readily relocate from older to younger leaf, leaving the possibility for deficiency symptoms in older leaves. Young plant tissues possess higher capability for response to in vitro culture, compared to older plant materials. This may explain the favourable responses recorded for the young stem explants in this study.

Results of Debauza and Pena (2001); Peddabonia et al. (2006) on the organogenesis of $C$. annuum confirmed the claim in this study that the standard medium for callogenesis of Capsicum anпиит is a semi-said state MS medium that is enhanced with BAP and IBA. Hassan et al. (1999); Dabauza and Peña (2001) however reported MS medium supplemented with silver nitrate to be suitable as an elongation medium, whereas NAA- and IBA - supplemented MS media enhances rooting in sequential experiments. Survival rate of the established calli ranged from $60-80 \%$.

$\underline{\text { Table } 9 \text { Contamination rate for explants obtained from control and polluted soils }}$

\begin{tabular}{|c|c|c|c|c|c|c|c|c|}
\hline \multirow{3}{*}{$\begin{array}{l}\text { No. of days after } \\
\text { initiation }\end{array}$} & \multirow{2}{*}{\multicolumn{2}{|c|}{ Leaf explants }} & \multirow{2}{*}{\multicolumn{2}{|c|}{ Stem explants }} & \multicolumn{4}{|c|}{ Contamination source } \\
\hline & & & & & \multicolumn{2}{|c|}{ Leaf explant } & \multicolumn{2}{|c|}{ Stem explant } \\
\hline & Control & Polluted & Control & Polluted & Control & Polluted & Control & Polluted \\
\hline \multicolumn{9}{|c|}{31 days-old explants } \\
\hline $1-7$ & - & + & - & - & - & $\mathrm{B}, \mathrm{F}$ & - & - \\
\hline $8-14$ & - & ++ & - & ++ & - & $\mathrm{B}, \mathrm{F}$ & - & $\mathrm{B}, \mathrm{F}$ \\
\hline $15-21$ & + & + & - & + & $\mathrm{B}, \mathrm{F}$ & $\mathrm{B}, \mathrm{F}$ & - & $\mathrm{B}, \mathrm{F}$ \\
\hline $22-28$ & + & ++ & - & + & $\mathrm{B}, \mathrm{F}$ & $\mathrm{B}, \mathrm{F}$ & - & $\mathrm{B}, \mathrm{F}$ \\
\hline $29-35$ & + & ++ & ++ & +++ & $\mathrm{B}, \mathrm{F}$ & $\mathrm{F}$ & $\mathrm{B}, \mathrm{F}$ & $\mathrm{F}$ \\
\hline $36-42$ & + & +++ & ++ & +++ & $\mathrm{F}$ & $\mathrm{F}$ & $\mathrm{B}, \mathrm{F}$ & $\mathrm{F}$ \\
\hline $43-49$ & ++ & ++++ & +++ & +++++ & $\mathrm{F}$ & $\mathrm{F}$ & $\mathrm{F}$ & $\mathrm{F}$ \\
\hline $50-56$ & +++ & ++++ & ++++ & +++++ & $\mathrm{F}$ & $\mathrm{F}$ & $\mathrm{F}$ & $\mathrm{F}$ \\
\hline \multicolumn{9}{|c|}{28 days-old explants } \\
\hline $1-7$ & - & - & - & ++ & - & - & - & $\mathrm{F}$ \\
\hline $8-14$ & - & ++ & - & +++ & - & $\mathrm{B}, \mathrm{F}$ & - & $\mathrm{F}$ \\
\hline $15-21$ & - & + & + & ++ & - & $\mathrm{B}, \mathrm{F}$ & $\mathrm{B}, \mathrm{F}$ & $\mathrm{F}$ \\
\hline $22-28$ & - & + & ++ & + & - & $\mathrm{B}, \mathrm{F}$ & $\mathrm{B}, \mathrm{F}$ & $\mathrm{F}$ \\
\hline $29-35$ & - & + & + & ++ & - & $\mathrm{B}, \mathrm{F}$ & $\mathrm{B}, \mathrm{F}$ & $\mathrm{B}, \mathrm{F}$ \\
\hline $36-42$ & + & +++ & ++ & ++ & + & B & $\mathrm{B}, \mathrm{F}$ & B \\
\hline $43-49$ & ++ & +++ & ++ & +++ & ++ & B & B & B \\
\hline $50-56$ & +++ & +++++ & ++++ & +++++ & +++ & B & B & B \\
\hline \multicolumn{9}{|c|}{ 21days-old explants } \\
\hline $1-7$ & - & - & - & - & - & - & - & - \\
\hline $8-14$ & - & ++ & - & + & - & B & - & + \\
\hline $15-21$ & + & ++ & - & +++ & + & B & B & $\mathrm{B}, \mathrm{F}$ \\
\hline
\end{tabular}

Legend: - No contamination; + not profuse; ++ slightly profuse; +++ profuse; ++++ very profuse; +++++ highly profuse.

$\mathrm{F}$ majorly fungal infection, $\mathrm{B}$ majorly bacterial infection. 


\section{CONCLUSION}

In this study, an effective procedure for callogenesis of Capsicum annuum explants obtained from pepper plants sown in oil-polluted soil had been developed, using BAP - and IBA - supplemented MS media in a semi-solid state This protocol could be very useful for callus production which could be used in large scale production of this cultivar of pepper from polluted soils over a short period of time; and offers a potential method for the genetic enhancement of the crop. Similarly, the ability of IBA to induce callus was documented. However, a lot of difficulties were observed during the induction of callus, over all the experiments, therefore a further investigation is needed to overcome these problems.

Acknowledgments: The authors wish to acknowledge the immense contributions the following postgraduate research assistants, Osazuwa Omoregbe, Eric Eboigbe, and Precious Okeoghene Ekhator. This study was carried out in the Plant Physiology Laboratory of the Nigeria Institute for Oil Palm, NIFOR, Benin City, and for this the authors are grateful. This research was privately funded.

\section{REFERENCES}

Aghaei, P., Bahramnejad, B., \& Mozafari, A.A. (2013). Effect of different plant growth regulators on callus induction of stem explants in Pistacia atlantica subsp. Kurdica. Plant Knowledge Journal 2(3), 108-112. http://www.sciencej.com/bahraminejad 22 3 2013 108_112.pdf

Agrawal, S., \& Chandra, N. (1983). Differentiation of multiple shoot buds \& plantlets in cultured embryos of Capsicum annuum L. var. mathania. Curr. Sci. 52, 645-646. http://dx.doi.org/10.1007/BF00044071

Agrawal, S., Chandra, N., Kothari, S.L. (1989). Plant regeneration in tissue cultures of pepper (Capsicum annuum L. cv mathania). Plant Cell, Tissue \& Organ Culture 16:47-55. http://dx.doi.org/10.1007/BF00044071

Amakiri, J.O. \& Onofeghara, F.A. (1984). Effect of crude oil pollution on the germination of Zea mays \& Capiscum frutescens. Environmental pollution 35, 159-167. http://dx.doi.org/10.1016/0143-1471(84)90136-3

Anoliefo, G.O. \& Vwioko, D.E. (1995). Effects of spent lubricating oil on the growth of Capsicum annum \& Lycopersicon esculentum. Pollution 88, 361-314. http://dx.doi.org/10.1016/0269-7491(95)93451-5

Bhojwani, S.S. \& Dantu, P.K. (2013). Plant Tissue Culture: An Introductory Text. In: Bhojwani SS \& Dantu PK (eds) Micropropagation. Springer, India. p 245-274.

Bretagne B., Chupeau, M.C., Chupeau, X., \& Faniliox, G. (1994). Improved flax regeneration from hypocotyls using Thidiazuran as a cytokinin source. Plant Cell Report 14, 120-124. http://dx.doi.org/10.1007/bf00233774

Caraballo, M.G., Oramas, G.G., García, S.A., Cruz, E.A., Bravo, K.Q., Caligari, P.D.S., \& García-González, R. (2010). Management of auxin-cytokinin interactions to improve micropropagation protocol of henequen (Agave fourcroydes Lem.). Chilean Journal of Agricultural Research 70(4), 545-551. http://dx.doi.org/10.4067/s0718-58392010000400003

Cheesbrough M. (2001). District Laboratory Practice in Tropical Countries, Part 2.Cambridge University Press, Cambridge. 355p.

Christopher, T. \& Rajam, M.V. (1996). Effect of genotype, explants \& medium on in vitro regeneration of red pepper. Plant Cell, Tissue \& Organ Culture 46:245-250. http://dx.doi.org/10.1007/bf02307101

Christopher, T. \& Rajam, M.V. (1994). In vitro clonal propagation of Capsicum spp. Plant Cell Tissue Organ Culture 38, 25-29. http://dx.doi.org/10.1007/bf00034439

Dabauza, M. \& Peña, L. (2001). High Efficiency organogenesis in sweet pepper (Capsicum annиum L.) tissues from different seedling explants. Plant growth Regulation 33, 221-229. http://dx.doi.org/10.1023/a:1017585407870

Harini, I. \& Sita, G. (1993). Direct somatic embryogenesis \& plant regeneration from immature embryos of chili (Capsicum annuum L.). Plant Science 89:107112. http://dx.doi.org/10.1016/0168-9452(93)90176-z

Hassan, M. A., Sarg, S.M., Elwan, M.W.M. \& Awny, S.A. (1999). Development of in vitro high frequency regeneration protocol for pepper (Capsicum annuum) plantlets from leaf sections. J. Agric. Sci. Mansoura Univ. 24(4):1951-1961.

Hopkins, W.G. \& Hüner, N.P.A. (2009). Introduction to Plant Physiology, 4th Edition. John Wiley \& Sons, Inc., Hoboken, USA.

Hyde, C. \& Phillips, G.C. (1996). Silver nitrate promotes shoot development \& plant regeneration of chile pepper (Capsicum annuum L.) via organogenesis. In Vitro Cell Dev. Bio. Plant 32,72-80. http://dx.doi.org/10.1007/bf02823134

Ikhajiagbe, B. \& Anoliefo, G.O. (2012a). Phytoassessment of a 5-month old waste engine oil polluted soil after augmentation with Pleurotus tuberregium. Current Research Journal of Biological Sciences 4 (1), 10 - 16. URL: http://maxwellsci.com/jp/abstract.php?jid=CRJBS\&no=169\&abs=03.

Ikhajiagbe, B. \& Anoliefo, G.O. (2012b). Substrate Bioaugmentation of Waste Engine Oil Polluted Soil. Research Journal of Environmental \& Earth Sciences 4(1), 60-67.
http://maxwellsci.com/jp/abstract.php?jid=RJEES\&no=157\&abs=10

Ittp://majiagbe, B. (2010). Phytoassessment of waste engine oil polluted soils after amendment and augmentation: synergism in bioremediation. Ph. D. Thesis
Department of Plant Biology and Biotechnology, University of Benin, Benin City, Nigeria.

Ikhajiagbe, B., Anoliefo, G.O., Omoregbee. O., \& Osigbemhe, P. (2014) Changes in the intrinsic qualities of a naturally attenuated waste engine oil polluted soil after exposure to different periods of heat shock. Resources and Environment 4(1), 45-53. http://dx.doi.org/10.5923/j.re.20140401.05

Jin, H., Deng, Z-C., \&He, H (2014)Effect of explant types \& plant growth regulators on direct regeneration in medicinal plant Pogostemon cablin. Plants $\begin{array}{llll}\text { Omics } & \text { Journal } & 7(5), & 322-327\end{array}$ http://www.pomics.com/jin $7 \quad 5 \quad 2014 \quad 322 \quad 327 . p d f$

Mineo, L. (1990). Plant tissue culture techniques. In: Goldman, C.A. (ed.) Tested Studies for Laboratory Teaching. Vol. 11. Proceedings of the Eleventh Workshop/Conference of the Association for Biology Laboratory Education (ABLE). pp 151-174.

Murashige, T. \& Skoog, F. (1962). A revised medium for rapid growth \& bioassays with tobacco tissue cultures. Physiol. Plant 15, 473-497. http://dx.doi.org/10.1111/j.1399-3054.1962.tb08052.x

Peddabonia, V., Thamidal, C. \& Karampuri, S. (2006). In vitro shoot multiplication \& plant regeneration in four Capsicum species using thidiazuron. $\begin{array}{lll}\text { Scientia } \quad \text { Horticulturae } & 107 & 117-122\end{array}$ http://dx.doi.org/10.1016/j.scienta.2005.06.010

Phillips, G.C. \& Hubstenberger, J.F. (1985). Organogenesis in pepper tissue cultures. Plant Cell, Tissue \& Organ Culture 4, 261-269. http://dx.doi.org/10.1007/bf00040200

Sharma, R. \& Shahzad, A. (2008). Thidiazuran (TDZ) induced regeneration from cotyledonary node explant of Abelmoschus moschatus Medik. L., (a valuable medicinal plant). World Journal of Agricultural Sciences 4 (4), 449-452. http://www.idosi.org/wjas4(4)/6.pdf

Taiz, L. \& Zeiger, E. (2010). Plant Physiology, 5th Edition. The Benjamin Cummings Publishing Company, Redwood City - California.

Vwioko, D.E. \& Fashemi, D.S. (2005). Growth response of Ricinus communis L (Castor Oil) in spent lubricating oil-polluted soil. Journal of Applied Sciences \& Environmental Management http://dx.doi.org/10.4314/jasem.v9i2.17294 